\title{
WITH MUSIC EDUCATION AGAINST UNIVERSITY DROPOUT? ON THE CONNECTION BETWEEN EXPERIENTIAL GROUP MUSIC SESSIONS AND THE UNIVERSITY DROPOUT PROCESS
}

\section{Preliminary findings, theoretical and practical background of the research}

Dropping out of school has been one of the most actual and common issues in education in recent years. It is present in practice and a well-defined concept in the literature. It is a complex and multifaceted process, the causes of which are increasingly being investigated both domestically and internationally (Kenderfi 2011, Stiburek 2017, Jungerta 2015, Frey 2014, Şahin 2014, Faria 2012, WuduGetahun 2009).

The analysed phenomenon entirely affects tertiary education, as well. It can be traced exponentially at the university level, both theoretically and practically. The dropout process deserves special attention in the first-year students' university education, mainly including the first term, which is considered the "most critical" period (Lukács-Sebő 2015). Beginning university studies is a big challenge compared to high school studies: it provides significant changes, new circumstances and conditions for young adults. They have to adapt to new social environments and cope with unknown situations.

Moreover, they need to develop new learning strategies. "During the 3-4-month period, the student is in a state of readiness and is forced to prepare for classes more or less regularly, whereas the subsequent 5-6-week exam period covers a phase of intensive learning. The temporal reorganisation, forms of learning, such as participating in seminars or preparing portfolios, different methods of supervision and assessment all require more and more advanced learning management skills and also encourage the student to develop them" (Gaskó 2006: 30).

In addition to academic life, the first-year university student also enters a changed system of social relations. Their family and friendships are undergoing both qualitative and quantitative changes. They meet new teacher personalities and have to adapt to new expectations. Appleton et al. (2006) describe students' integration as a multidimensional concept (also as one of the best predictors of learning success): academic (earned credits, time spent on learning), behavioural (class attendance, postponement, work outside school), and psychological factors all determine students' attachment to the institution (Koltói, 2013). The study of the adaptation and integration of university students into the social system offered by the university is, therefore, also an essential area of research, which investigates the causes of dropout (Kanczné-Tóth 2018).

To his end, the Ratio research group, founded in 2017, started its research at the Faculty of Education at J. Selye University. The longitudinal study began in the form of pilot research, which was carried out among the students of J. Selye University in Komárom. In the academic year 2018/2019, the analysis extended to three tertiary institutions in the Carpathian Basin, namely the II. Ferenc Rákóczi Hungarian University of Transcarpathia (Beregsk, Ukraine), the Christian Partium University (Oradea, Romania) and the Faculty of Hungarian Language Teacher Training at the University of Novi Sad (Subotica, Serbia).

Based on the results examined and received so far, the fears, insecurities, anxieties and doubts of the first-year students became remarkable. These are essential factors in integration into university life and relationships and in the process of successful university studies. Based on the results examined and summarised so far, it is necessary to highlight the following:

High scores were achieved by students' fears about social life: $31.20 \%$, their worries about educators: $37.10 \%$, about the curriculum: $44.40 \%$, and their concern about requirements: $45.50 \%$. Their 
uncertainty about themselves are outstanding: $50.10 \%$, but above all, their level of fears of learning is significantly high, up to $61.10 \%$ (Figure 1 ).

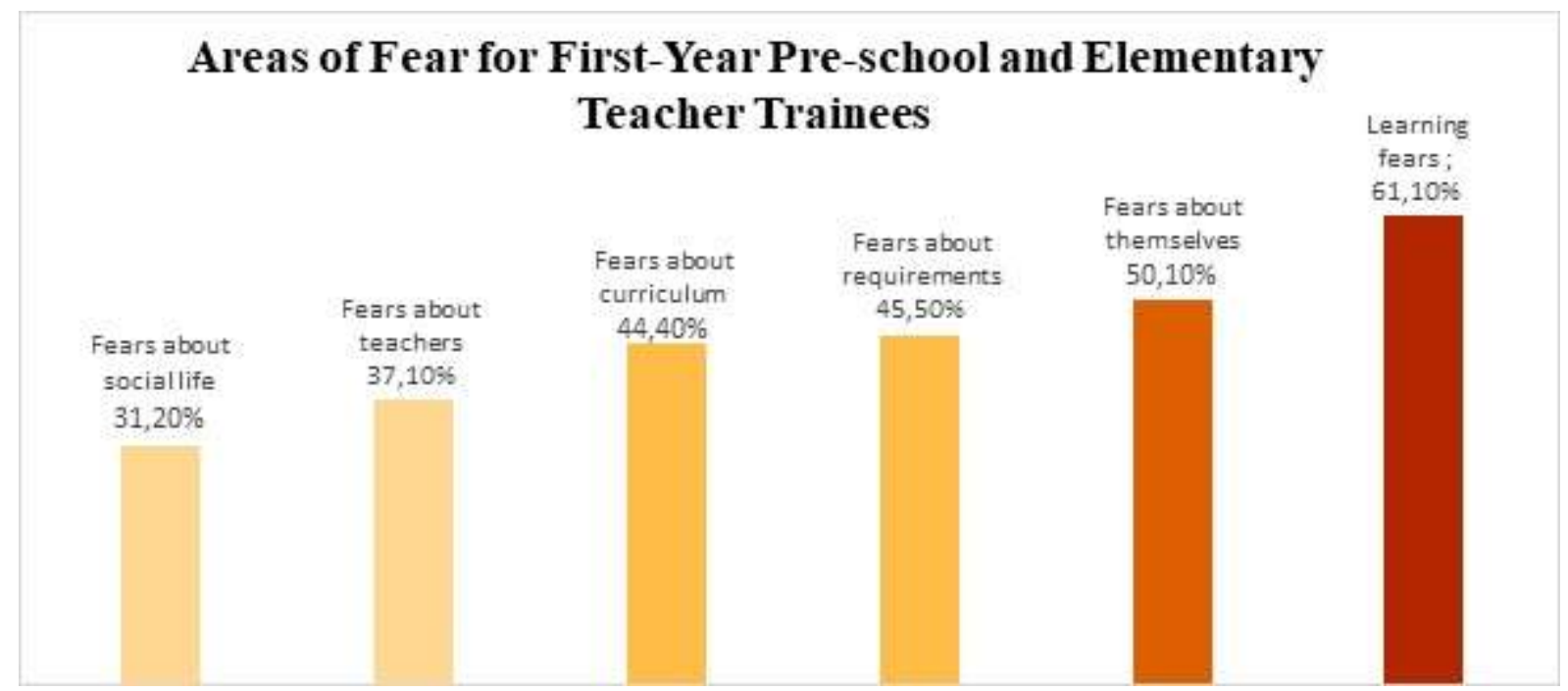

Figure 1: Areas of Fear for First-Year Pre-school and Elementary Teacher Trainees

Thus, the participants' fears in the study, which showed a significantly high percentage, were related to learning, i.e. the greatest fear of first-year teacher trainees is about learning (61.1\%). They are also afraid of schedules (39\%) and performance (37\%). They voiced the reasons for their fears as follows: "I can't pass; I fail the exam and have to postpone."

Thus, the studies' results have shown so far that the fears, insecurities, worries and anxieties of firstyear teacher trainees about university studies cannot be ignored. Their indicators are significantly high when it comes to considering themselves and especially learning and successful completion of their studies. ${ }^{1}$

\section{Music education and teacher training}

Based on the research results presented above, it can be concluded that special attention should be paid to the objective and subjective circumstances of first-year teacher trainees' study.

At the Faculty of Education of J. Selye University, music education is a crucial part of teacher training, especially in the Department of Pre-school and Elementary Education, as well as in its related study programs and individual grades. Music education starts in the first term of the first year of study within the subject called Basics of Music Theory and Music Education. The content and topics of the course, as its name suggests, cover all the elements of music theory and music education that are necessary for musical literacy, classes focused on perception, musical reproduction and creative activities. Consequently, its content covers the unity of affluent theoretical knowledge and demanding practical knowledge. ${ }^{2}$ The experience of these necessary abilities and skills, both on a theoretical and practical

\footnotetext{
${ }^{1}$ The results of the research of the Ratio research group and the conclusions and pedagogical recommendations have been made available to the public in several scientific publications. Thus, among others: Horváth-Tóth 2018; Horváth-Tóth 2019; Horváth 2018; Kanczné Nagy 2019; Kanczné Greater Czech Republic 2018; Kanczné Nagy-Tóth 2018; Nagy-Horváth-SzabóováKanczné-Nagy 2018; Nagy-Horváth-Szabóová-Kanczné-Nagy-Orsovics-Strédl 2019; Nagy-Szabóová-Horváth-Kanczné-TóthBakos-Orsovics-Strédl 2018; Tóth-Bakos 2018; Tóth-Bakos-Tóth 2018.

${ }^{2}$ Content of the Basics of Music Theory and Music Education: 1.) General knowledge on musical literacy. Students become familiar with the line system, master the basics of music theory and commonly used musical terms. 2.) Getting to know music literature and nursery rhyme collections suitable for pre-school children. Topics of the course: rhythm, tempo, dynamics, musical note writing and reading, accidentals-modified notes, enharmonic sounds, intervals, scales (diatonic, modal), chords,
} 
level, is a prerequisite for completing practical music subjects (instrumental playing, intonation and rhythmic education, instrumental activity, chorus) in further terms of training. So it is one of the most demanding subjects that cause difficulties in passing the end-of-term exam and state exam, and which is a requirement for achieving the necessary number of credits and continuing university studies.

Aware of all this, first-year pre-school teacher trainees often voice their fears about successfully completing this music subject. In particular, they are worried that they will not be able to master the basics of musical literacy and that they will not have sufficient musical abilities and skills (sense of rhythm, vocal expression, musical literacy) to successfully complete the course. Therefore, they nurture some 'aversion', fear, anxiety about music education, unfortunately, immediately in the early stages of their university studies. Nevertheless, this is a paradox because:

Music is a human-forming force that affects the whole personality. Overall, it has a significant impact on the general development of an individual. It predisposes us to be more receptive to the beautiful; moreover, it shapes taste and human behaviour. Music education is only a small segment of institutional training, yet it can strongly influence the individuals' general development. It directly induces emotions, affects the development of cognitive and emotional competencies and physical and mental health. Consequently, music education is a crucial part of educational work and personality development. Last but not least, music is considered one of the central research topics in various examinations. According to their fields of expertise, music researchers, music educators, music historians, psychologists, doctors, and therapists study music's impact on ability development, talent development, concentration, socialisation and community building processes. Music aids in achieving spiritual harmony and well-being, in preserving and nurturing health, in relieving stress and rehabilitating. It is, therefore, a tool in education, personality development, therapy and prevention (Falus 2016).

Music requires twice as much brain activity as speech, and instrumental singing activates the entire pallium. As a result, the many skills that are used while music-making also aid in developing other areas. 'Musicians have a demonstrably more advanced corpus callosum - a tract which connects the two cerebral hemispheres of the brain - than ordinary people. Accordingly, there is much greater interoperability between skills related to emotional intelligence, logical thinking and speech than in general' (Marton, Janurik 2016).

Certain elements of music are important, which, according to Zoltán Kodály, are effective "educational tools." In his opinion, "Rhythm develops attention, concentration, steadiness and ability of innervation. Melody opens up the world of feelings; it changes in intensity, tone, and it is the sharpener of our auditory organ. Singing is, after all, such a versatile bodily function that the effect of physical education is immeasurable - in case' soul education' would not be important to someone. Its health benefits are well known" (Kodály 1974: 95). It is in this spirit that Kodály had developed and created his musicpedagogical method.

Music is, therefore, an essential condition for both general development and educational work. It evokes emotions, has a therapeutic effect and affects both the individual's intellect and physicalmental-emotional world. As a result, in the last few years or decades, the impact of music and musical activities has become a central topic of more and more research. The requirements of modern education are also met by creative activities that have a broad transfer effect, spread their impact over several areas, a multitude of skills and have a positive effect on the development of the whole personality as well.

musical instruments; nursery rhymes - classification according to their content, acquisition of their text and rhythm; Requirements for completing the course: 1.) test (theory, musical literacy); 2 .) creating a collection of nursery rhymes suitable for pre-school children. 


\section{The aim, process and realisation of the research}

The facts summarised above, resp. the learning fears of first-year (pre-school) teacher trainees as well as their concerns about the course Basics of Music Theory and Music Education, inspired the realisation of this survey. The outlined aspects justified examining the students' opinions, views and experiences, and then drawing the necessary conclusions and lessons from them - by all means, with the intention of reinforcing the students' university attachment.

Research objectives: To assess the opinions of first-year (pre-school) teacher trainees and the objective and subjective circumstances (defined by them) that have helped or hindered them in meeting the compulsory study requirements for the subject of Basics of Music Theory and Music Education. Further, the research aims at mapping out students' experiences during the study and exam period, which provided reinforcement in their relationship to their university studies.

The present study outlines details of the results of the analysis of the students' opinions.

The study was carried out in the winter term of the 2019/2020 academic year, after the first term, more exactly after writing the end-of-term tests. The study involved 76 first-year students of the PreSchool and Elementary Education study programme. This number differs from the number of students evidenced at the beginning of the academic year as a total of 86 students applied for the subject at the beginning of the year, but by the end of the 13 week study period, 10 students had dropped out. As a result, 76 pre-school teacher trainees (of which 72 are first-year and 4 are second-year students, the latter retaking the subject from the previous year) were involved in the research. The gender distribution of the participants: 72 women and 4 men (Figure 2).

\section{Persentage distribution of the participants by gender}

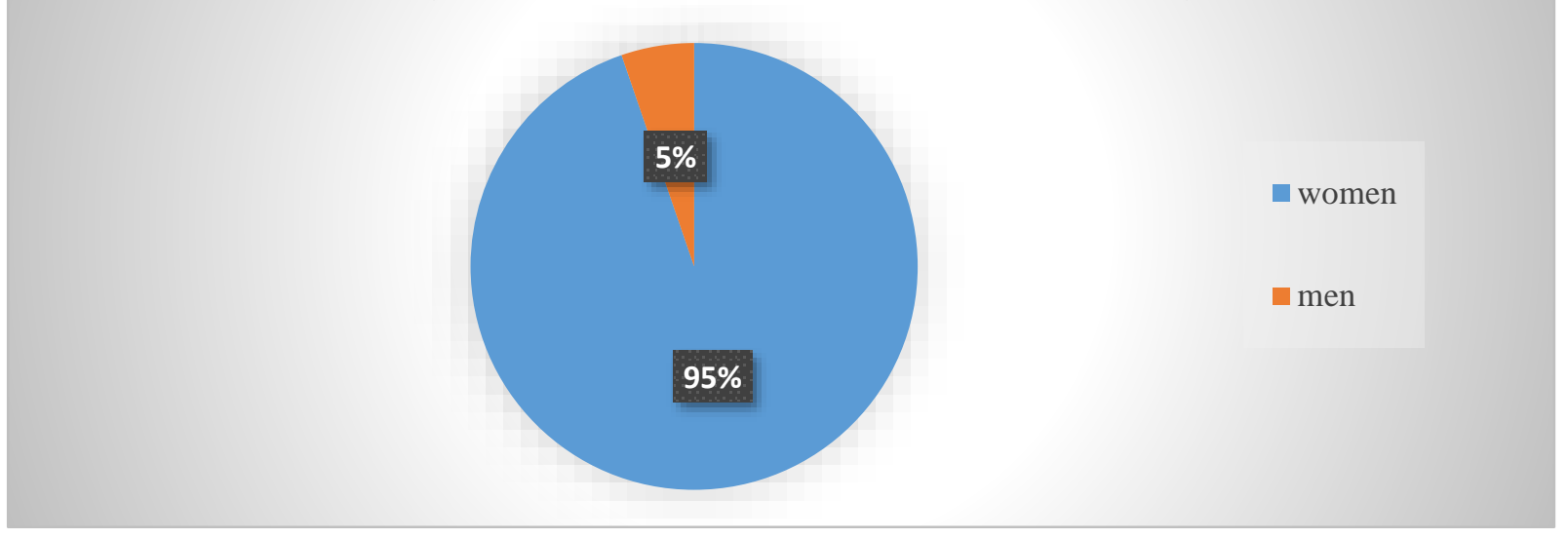

Figure 2: Percentage distribution of the students by gender

The research was conducted in writing. The students expressed their opinions, wrote their answers and shared their experiences on precisely formulated questions, which were related to the content of the subject and to the knowledge acquired during the study period. Also, the questions focused on either helpful or detrimental circumstances that affected the successful fulfilment of the requirements of the course. Students were not given any stipulations concerning the answers; they were free to express their opinions to any extent.

The questions were focusing on the following aspects:

- Which of the 11 primary topics of the course (rhythm, tempo, note writing, modifying signs, enharmonic sounds, intervals, sequences, chords, dynamics, musical instruments, rhymes) do you consider the most challenging material?

- Explain what exactly caused you difficulty (/difficulties) in the process of acquiring the named curriculum.

- Name which session/class you liked best.

- Describe the positive effects, benefits and results of this session. 


\section{Research results}

1. For the first question, students identified four of the 11 topics in the subject as difficult to learn. These appeared in the following proportions: 48 of the 76 students marked intervals, scales: 42 , chords: 28, accidentals-modified notes: 15 (Some students marked two curricula.) (Figure 3).

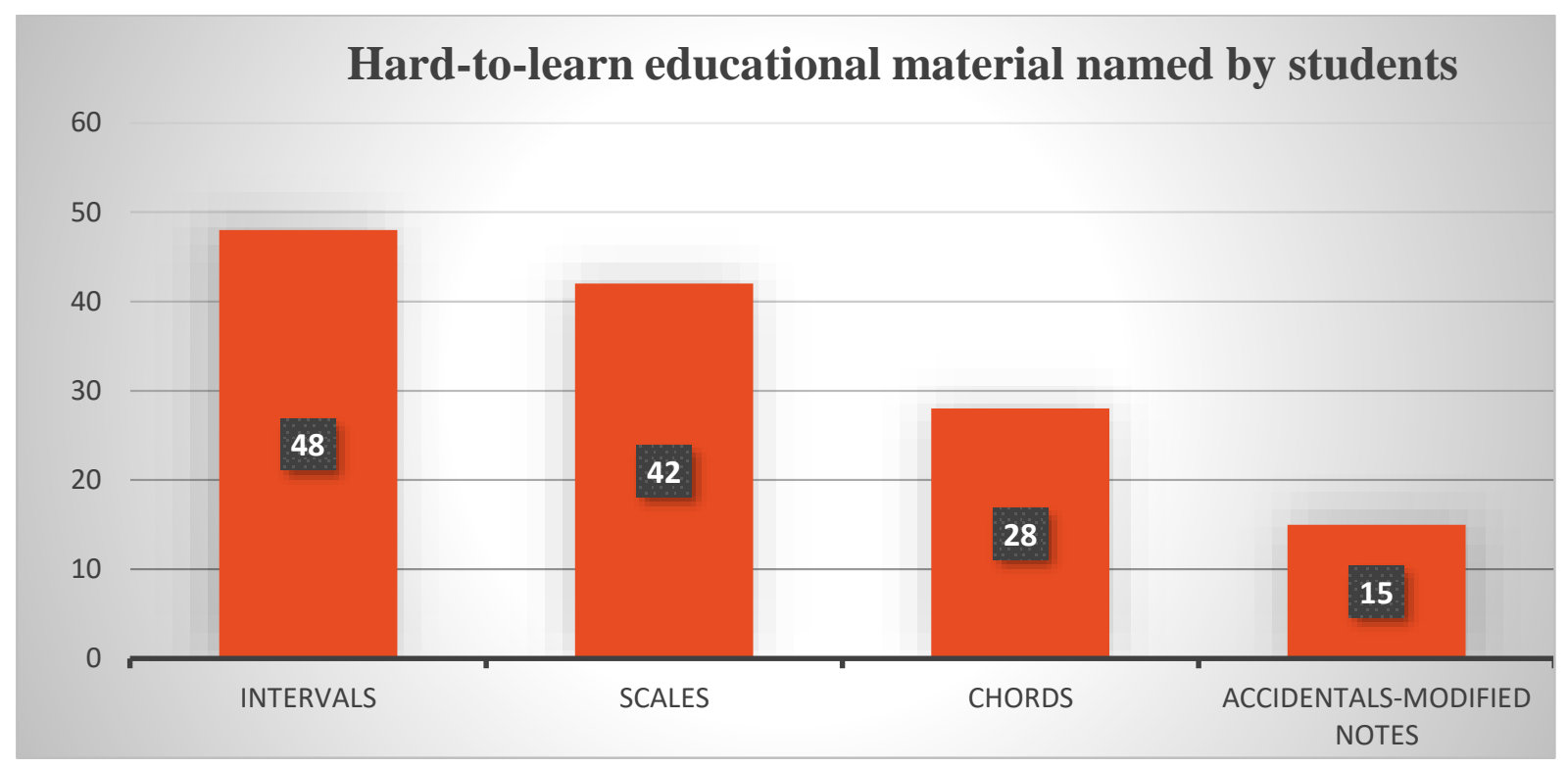

Figure 3: Hard-to-learn curricula named by first-year (pre-school) teacher trainees

2. In the second question, students were asked to describe the difficulties in the process of mastering the chosen curriculum. With this question, the researchers intended to identify particular difficulties and to draw conclusions to improve the situation.

Based on the students' responses and reasoning, the logical approach was clearly the problem. It is also necessary to activate logical thinking when using intervals, strings, chords and, to some extent, modifying signals. Mechanical learning is not appropriate for these topics. It is not enough to look for connections, to draw conclusions and to record information without thinking. This was clearly stated in their justifications:

"For me, the intervals were the hardest because I had to count a lot there."; Intervals is the most difficult material because it is difficult to recall them and calculate in the line system."; The sequences were the hardest because the logic was complicated there."; I had a hard time with the major and minor curriculum because somehow I couldn't memorise what was going on; "Intervals and sequences were the hardest for me. I know it in theory but not really in practice. I couldn't figure out its logic."; The most difficult curriculum is chords. I can't calculate the sounds. The logic for the sequences was complicated for me."

Among the answers, however, the factor of lack of time also appeared, resp. The possibility of little practice and the lack of qualified supervision in the process of preparation and training at home.

"The major and minor scales were the most difficult because they require a lot of practice;" Intervals and sequences were difficult. I hadn't studied music before, and there was no one at home to practice with me;" The major and minor sequences were the most difficult because there are many of them, and it is hard to memorise. Anyway, it was clearly explained."

Finally, the music curricula indicated by the students were ultimately raised to such a level that by the end of the exam period, 98 percent of the students met the expectations, according to the grading scale (A, B, C, D, E). Consequently, the studied course can be successfully completed with the help of regular practice, systematic learning and active participation in seminars. This is also supported by 
students' opinions: "Overall, the curriculum was not difficult, but we had to learn more than usual."; I was preparing for every class, so even as a beginner, I managed to write the test for A."

3. With the third and fourth questions, our intention was to shed light on which music-pedagogical session won the students' interest the most. It is important to assess which activity (/activities) help(s) the teaching-learning process to the greatest extent; hence it is ultimately a condition for a successful teaching-learning process, for the effective and quality development of knowledge, abilities and skills.

The experiential and learning-enhancing activities highlighted by the students are the following: "the nursery rhyme collection, making a nursery rhyme noticeboard in small groups whilst listening to music; playful practice of the rhythm of rhymes in-class work; practice in classes with teacher assistance and supervision; illustrating the intervals with an auditory demonstration of the piano."

The aforementioned occupations have also been proven right in quantitative terms. A particular creative group session, chosen by 67 of 76 students, gained significant popularity: the nursery rhyme collection, resp. making a nursery rhyme noticeboard in small groups while listening to music. In the lesson, students collected rhymes in groups of 3-4 on specific topics (holidays, seasons, nature, animal verses, counting-out rhymes, games, etc.) using noticeboards. The groups were free to choose any forms of adaptation: they could use books and their smartphones for help, and they could draw and glue for illustration. At the end of the class, the groups' works were presented and evaluated. This session was considered exciting. The most popular features of the session were: teamwork, the opportunity for creative work, the joy of learning together, the liberated atmosphere of the class. All this is clearly reflected and justified in the students' opinions:

"The lesson on which we were learning nursery rhymes was very cheerful and unconventional; When we collected rhymes it was fun learning"; "The best lesson was when we made nursery rhyme noticeboard because it was creative;" "For me, making the nursery rhyme noticeboard was the most exciting. We were listening to music whilst writing the rhymes. This made it easier to memorise the rhymes;" "The best experience was the nursery rhyme-lesson because we were working in teams;" "I liked making the nursery rhyme noticeboard the best because we could be creative and draw ideas freely into our collection;" "I enjoyed the nursery rhyme-lesson as we could use our creativity;" "Collecting rhymes in groups made it easier to do the same task at home;" "My favourite activity was making the nursery rhyme-book because I got to know many new rhymes, and I was able to show my creativity as well;" "The group lesson improved cooperation;" "During the term, the compilation of the rhyme collection was the best because it brought the group together;" "The biggest experience was working together whilst listening to music. It would be nice to have more of these lessons!"

Students' opinions focused on experiences were closely followed by three additional sessions, marked as 42, 31, 29 (Figure 4):

rhythm practice with nursery rhymes together in class; practicing musical literacy in class with the teacher's supervision; practicing and demonstrating the intervals with audio aid, piano. The students expressed their ideas about these activities in the following way: "I enjoyed all the classes because I love music. But I particularly liked when we were clapping to the rhythm;" "For me, the most experiential class was practicing rhymes. Clapping to rhythm in different playful shifts. Everyone was involved and active in this;" "The most interesting thing for me was clapping to the rhythm because that way I could more easily understand and grasp the length of the rhythm values and the essence of times;" The biggest experience: when we were clapping to the rhymes of the verses because it made it easier for me to learn. It was learning by playing;" "For me, the best session was to practice writing in the sheet music notebook because the teacher immediately warned me of my mistakes. This is how I understood and memorised the material more effectively;" "It really helped hear the intervals as the teacher was playing the piano. I heard the sounds' going up and down'"; "Since I hadn't studied music before, it was hard for me. But teamwork, clapping and practicing together made learning very easy." 


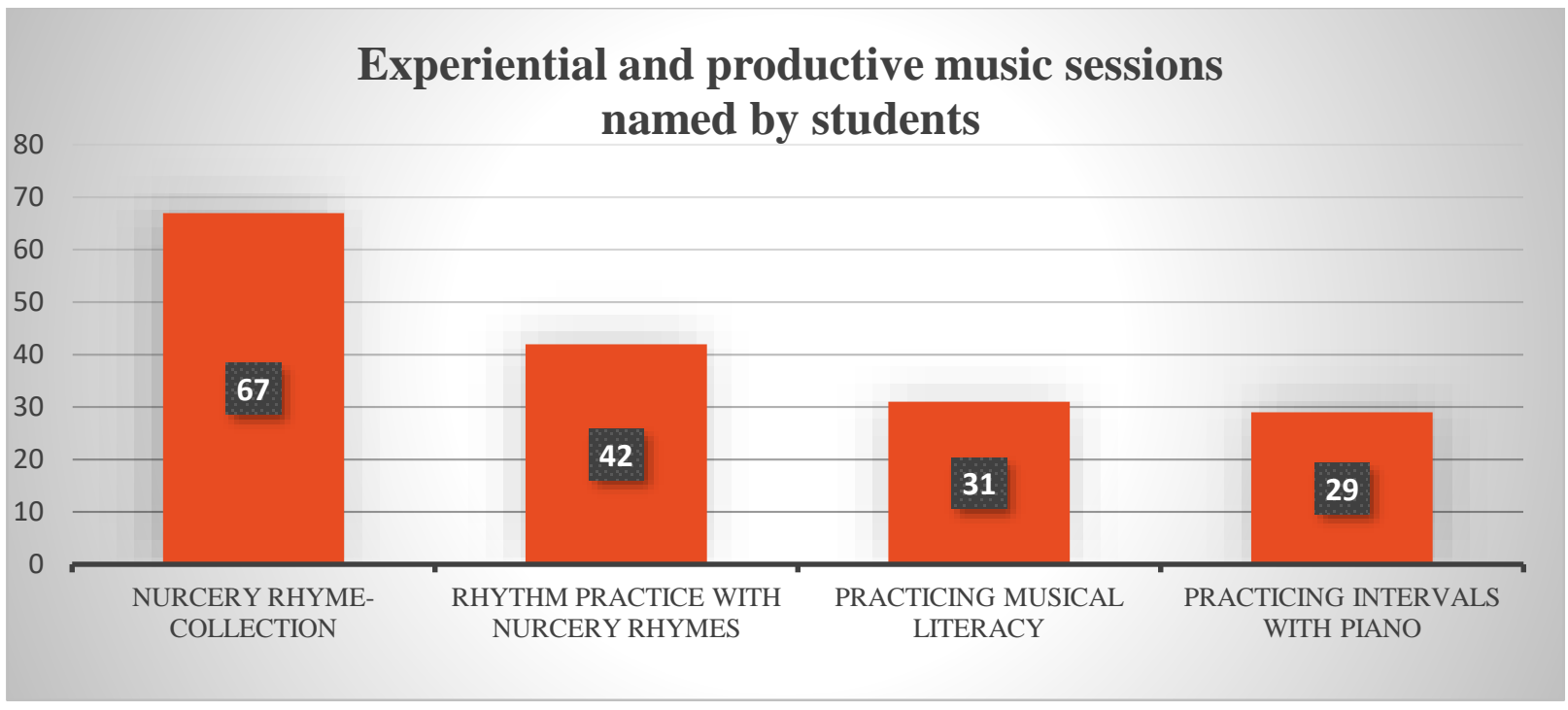

Figure 4: Experiential and productive music sessions chosen by students

\section{Summary}

Summarising the students' opinions and the content of their answers, the research was primarily focusing on the learning-enhancing factors, the acceptance and memorising of the curriculum, and on the successful completion of the study requirements during the study-and exam period.

The analysis of the overall results suggests that the following features are important for students: experiential learning, creative activities and a creative atmosphere, interpersonal factors such as teamwork and the teacher's effective, helpful attitude and colourful illustrations. All this is supported by the opinions of the students and their experiences they gained during the lessons. Based on the results, it can be stated that creative music sessions have a positive effect on the complex development of skills and personality, on the quality of academic performance and some psychological factors to reduce anxiety, cooperation and, last but not least, to positively affect their attitude towards university studies. The results can be explained by systematic work, regular group practice and focused attention. Music education activates students with a variety of auditory, visual and motor stimuli. "With music, we don't only learn music. Singing liberates, encourages, heals from inhibitions and shyness. It concentrates, improves physical and mental disposition, makes you feel like working. It makes you more suitable and accustomed to attention and discipline" (Kodály, 1974: 304).

Creative group activities as well as common creations have a rich emotional content, they evoke a series of experiences, so they also contain elements of experiential pedagogy (Csehi-Kanczné, 2018). The music-pedagogical experiences carry creative and experiential values that can be lifelong for young people. "Even if there is only one moment, the magnitude of a life can be measured on the size of this moment" (Kanczné 2007: 123) As a result, diverse 'stimulus effects,' experiential trainings and sessions together help memorise body of knowledge, develop skills and a complex personality.

\section{Conclusion}

The creative atmosphere of the teaching-learning process and experiential musical activities significantly contribute to the development of skills, to the acquisition and long-term memorisation of the curriculum and even have a positive impact on the development of higher psychic functions. Its influence transcends the boundaries of the content and material of music and determines the development of the whole personality. ${ }^{3}$ Finally, all of these aspects help students integrate into

\footnotetext{
${ }^{3}$ See also: TÓTH-BAKOS, A.: Mozartov efekt - môže hudba zlepšit' inteligenciu a kognitívne schopnosti? 2015, TÓTH-BAKOS, A. - CSEHIOVÁ, A.: Music and Brain - Music Training Transfer. INTED 2016 Proceedings: 10th International Technology,
} 
university life and complete their university studies successfully. "The artistic experience is a complex content of consciousness and spiritual state, into which emotional, intellectual and wilful elements, reality and imagination, precisely expressed thoughts, feelings, desires and aspirations - that have not reached the level of consciousness - are intertwined. It is in this way that the experience captures the person so deeply and in many ways. There are huge pedagogical opportunities in this" (Dobray 1983: 11).

\section{References}

- CSEHI, A. - KANCZNÉ NAGY, K.: Az élménypedagógia helye és szerepe a felsőoktatásban. Neveléstudományi kutatások a Kárpát-medencei oktatási térben. IV. Kárpát-medencei Oktatási Konferencia tanulmánykötete. Nagyvárad, 2018. p. 362-363. ISBN 978-80-8122-310-5

- DOBRAY, I.: A zenehallgatás feladatrendszere és módszere. Budapest: Tankönyvkiadó, 1983. 112 p.

- FALUS, A.: Zene és egészség. Zene-Egészség-nevelés-test-lélek. Budapest: Kossuth Kiadó, 2016. 303 p. ISBN 9789630986304

- FARIA, C. - FREIRE, S. - GALVÁO, C. - REIS, P. - BAPTISTA, M.: Students at risk of dropping out: how to promote their engagement with school science? Science Education International, 2002. Vol. 23, No.1, March 2012, 20-39

- FREY, A - BALZER, L. - RUPPERT, J. J.: Transferable competences of young people with a high dropout risk in vocational training in Germany. International Journal for Educational and Vocational Guidance, 2014. 14:119-134 DOI 10.1007/s10775-013-92578

- GASKÓ, K.: A tanulás pszichológiai értelmezése. In: M.Nádasi (szerk.): A gyakorlati pedagógia néhány alapkérdése. Hatékony tanulás. Budapest: Bolcsész Konzorcium, 2006. p. 20-40.

- HEGYI-HALMOS, N.: Az iskolai pályaorientáció szerepe és gyakorlata a hazai köznevelési intézményekben. A pedagógusok vélekedései a pályaorientáció iskolai szerepéről a gimnáziumokban (2016): http://ppkteszt.elte.hu/file/Hegyi Halmos Nora dissz.pdf

- HORVÁTH, K. - TÓTH, P.: Interakciós stílusról alkotott nézetek vizsgálata pedagógushallgatók körében. Új kihívások és pedagógiai innovációk a szakképzésben és a felsőoktatásban, A VIII. Trefort Ágoston Szakképzés- és Felsőoktatás-pedagógiai Konferencia tanulmánykötete, 2018. p. 21-55. ISBN 978-963-449-148-4

- HORVÁTH, K. - TÓTH, P.: Milyen az ideális tanári interakció a pedagógushallgatók szerint? Oktatás - Gazdaság - Társadalom, Hera Évkönyvek VI., 2019. p. 389-408. ISBN 978-615-565703-0. ISSN 2064-6755

- HORVÁTH, K.: A hallgatói elégedettség mérésének pilot kutatása a Selye János Egyetem Tanárképző Karán. Kutatás és innováció a Kárpát-medencei oktatási térben: 3. Kárpát-medencei Oktatási Konferencia. Tanulmánykötet. Nagyvárad: Partiumi Keresztény Egyetem, 2018. p. 648666. ISBN 978-963-449-115-6

- JUNGERTA, T. - ALMA, F. - THORNBERGA, R.: Motives for becoming a teacher and their relations to academic engagement and dropout among student teachers. Journal of Education for Teaching: International research and pedagogy, $2015.40: 2$, 173-185, DOI: 10.1080/02607476.2013.869971

- KANCZNÉ NAGY, K.: A logoterápia és egzisztenciaanalízis alkalmazásának lehetőségei a nevelésben. Gyermek-Nevelés-Pedagógusképzés. Budapest: Trezor Kiadó, 2007. 123. p. ISSN $1589-7370$ 
- KANCZNÉ NAGY, K. - CSEHIOVÁ, A.: Elsőéves tanár szakos hallgatók egyetemi képzéssel kapcsolatos előzetes elvárásainak és félelmeinek vizsgálata, körében. Új kihívások és pedagógiai innovációk a szakképzésben és a felsőoktatásban, A VIII. Trefort Ágoston Szakképzés- és Felsőoktatás-pedagógiai Konferencia tanulmánykötete, 2018. p. 56-65. ISBN 978-963-449-1484

- KANCZNÉ NAGY, K. - TÓTH, P.: „Azért vannak a jóbarátok...” avagy, a lemorzsolódás-kutatás pilot vizsgálatának eredményei a Selye János Egyetemen. Kutatás és innováció a Kárpát-medencei oktatási térben: 3. Kárpát-medencei Oktatási Konferencia. Tanulmánykötet: 3. Kárpát-medencei Oktatási Konferencia. Nagyvárad: Partiumi Keresztény Egyetem, 2018. p. 733-759. ISBN 978963-449-115-6.

- KANCZNÉ NAGY, K.: „Minden új ember egy rejtély, amelyen dolgoznunk kell.” Oktatás Gazdaság - Társadalom, Hera Évkönyvek, 2019. VI. p. 290-311. ISBN 978-615-5657-03-0. ISSN 2064-6755

- KENDERFI, M.: Pályaorientáció. Szent István Egyetem, 2011. https://www.tankonyvtar.hu/hu/tartalom/tamop412A/2010-0019 palyaorientacio/ch01.html

- KODÁLY, Z. (1974): Visszatekintés. Budapest: Zenemúkiadó, 1974. 346 p. ISBN 9633300347

- KOLTÓI, L.: Észlelt hallgatói kompetenciák. 2013. online https://www.felvi.hu/pub bin/dload/felsooktatasimuhely/FeMu/2013 3 4/femu 201334 81-92 koltoi.pdf

- LUKÁCS, F. - Sebő, T.: Az egyetemi lemorzsolódás kérdőives vizsgálata. Iskolakultúra, 2015, 25. évf., 10. sz.

- MARTON, Á., JANURIK, M. (2016): Zenei készségfejlesztés kisgyermekkorban. In: PEDAGÓGIAI FOLYÓIRATOK. Új köznevelés. 2016/4, 72. évf. 4. sz.

- NAGY, M. - HORVÁTH, K. - SZABÓOVÁ, E. - KANCZNÉ NAGY, K.: Elsőéves hallgatók véleménye a tanári kompetenciákról körében. Új kihivások és pedagógiai innovációk a szakképzésben és a felsőoktatásban, A VIII. Trefort Ágoston Szakképzés- és Felsőoktatás-pedagógiai Konferencia tanulmánykötete, 2018. p. 56-65. ISBN 978-963-449-148-4

- NAGY, M. - HORVÁTH, K. - SZABÓOVÁ, E. - KANCZNÉ NAGY, K. - ORSOVICS, Y. - STRÉDL, T.: A lemorzsolódás vizsgálata a Selye János Egyetem tanárképző karán a nappali és levelezős óvópedagógus képzésben utánkövetéssel. Oktatás - Gazdaság - Társadalom, Hera Évkönyvek, 2019. VI. p. 23-33. ISBN 978-80-8122-333-4

- NAGY, M. - SZABÓOVÁ, E. - HORVÁTH, K. - KANCZNÉ NAGY, K. - TÓTH-BAKOS, A. - ORSOVICS, Y. - STRÉDL, T.: A lemorzsolódás okainak vizsgálata a harmadéves óvópedagógus hallgatók körében. Kutatás és innováció a Kárpát-medencei oktatási térben: 3. Kárpát-medencei Oktatási Konferencia, Tanulmánykötet: 3. Kárpát-medencei Oktatási Konferencia. Nagyvárad: Partiumi Keresztény Egyetem, 2018. [CD-ROM] p. 909-929. ISBN 978-963-449-115-6

- ROBINSON, K. - ARONICA, L.: Kreatív iskolák. Budapest: HVG Kiadó Zrt., 2018. ISBN 978-963304-551-0.

- ŞAHIN, M.: The Relationship between Instructors Professional Competencies and University Students. School Engagement, Educational Sciences: Theory \& Practice, 14(2) 581-584 Educational Consultancy and Research Center, 2014. www.edam.com.tr/estp DOI: 10.12738/estp.2014.2.2003

- STIBUREK, Š. - VLK, A. - ŠVEC, V.: Study of the success and dropout in the higher education policy in Europe and V4 countries. Hungarian Educational Research Journal 2017, Vol. 7(1) 43-56, DOI: 10.14413/herj.2017.01.04. ISSN 2064-2199. 
- TÓTH-BAKOS, A.: A lemorzsolódás-kutatás pilot vizsgálatának eredményei a Selye János Egyetemen. Kutatás és innováció a Kárpát-medencei oktatási térben: 3. Kárpát-medencei Oktatási Konferencia. Tanulmánykötet: 3. Kárpát-medencei Oktatási Konferencia. Nagyvárad: Partiumi Keresztény Egyetem, 2018. [CD-ROM]. p. 717-732. ISBN 978-963-449-115-6

- TÓTH-BAKOS, A. - CSEHIOVÁ, A.: Music and Brain - Music Training Transfer. INTED 2016 Proceedings: 10th International Technology, Education and Development Conference. Valencia. USB. WoS. 2016. p. 1726-1732. ISBN 978-84-608-5617-7. ISSN 2340-1079

- WUDU MELESE - GETAHUN FENTA: Trend and causes of female student's dropout from teacher education institutions of Ethiopia: the case of Jimma University. Ethiopian Journal of Education and Science, Vol. 5. No. 1. September, 2009. ISSN 1998-8907 DOI: 10.4314/ejesc.v5i1.56309 